\title{
Social and Environmental Disclosure by Parastatals and Companies Listed on the Botswana Stock Exchange
}

\author{
Christian J. Mbekomize ${ }^{1} \&$ Lillian Wally-Dima ${ }^{1}$ \\ ${ }^{1}$ Faculty of Business, University of Botswana, Gaborone, Botswana \\ Correspondence: Christian J. Mbekomize, Faculty of Business, University of Botswana, Private Bag 00701, \\ Gaborone, Botswana. E-mail: mbekomizecj@mopipi.ub.bw
}

Received: February 15, 2013 Accepted: March 8, 2013 Online Published: July 3, 2013

doi:10.5539/jms.v3n3p66 URL: http://dx.doi.org/10.5539/jms.v3n3p66

\begin{abstract}
The need to communicate social and environmental effects of business operations to society has been with us for over four decades now. However, due to diverse factors the pace of introducing social and environmental reporting in developing countries has been slow. The purposes of this study are: to determine whether companies listed on the Botswana Stock Exchange and Parastatals in Botswana report on social and environmental issues in their annual reports and to what extent they disclose such information; to establish whether there is a difference in the level of reporting between listed companies and parastatals; and to determine whether size, type of industry and ownership influence the extent of disclosure. All listed companies and parastatals operating in Botswana formed the population of this study. Secondary data obtained from annual reports was reviewed and content analysis was employed to determine the extent of social and environment reporting. The extent of disclosure was measured using number of sentences describing the key themes such as human resources, environmental issues and community involvement. Regression analysis was used to find the association between dependent variable (extent of disclosure) and three independent variables namely size of the company, ownership and type of industry. The results suggest that social and environment reporting exists in Botswana entities and listed companies tend to disclose more than parastatals. The findings also show that size, type of industry and ownership are not good predictors of the level of social and environmental disclosure in Botswana entities.
\end{abstract}

Keywords: social and environmental disclosure, parastatals, listed companies, Botswana Stock Exchange, annual reports

\section{Introduction}

\subsection{Introduction to Social and Environment Reporting}

Social and environmental accounting (SEA) can be traced back to the 1970s in the annual reports of Abt Associates, the American consultancy firm (Wikipedia, 2012). Since then SEA has gained attraction in the corporate world and among the academic researchers due to societal concerns about the effects of environmental pollution, global warming and natural resource depletion by business's operations vis-à-vis corporate social responsibility. Different authorities, both government and non-government, have issued directives and guidelines encouraging organisations to report on their economic performance as well as social and environmental performance. Particularly, Global Reporting Initiatives (GRI), a non-profit organisation constituted by a wide range of stakeholders, has since 2000 issued guidelines regarding contents of what is known as Sustainability Report. A Sustainability Report is described as an organisational report that gives information about the economic, environmental, and social and governance performance. Depending on the size of the organisation and level of details in the report, sustainability information can be incorporated in the entity's annual report or in a standalone statement. This study is focusing on the social and environmental disclosures in the annual reports of entities in Botswana.

According to Guthrie and Mathews (1985) social and environmental disclosure (SED) refers to the provision of financial and non-financial information relating to an organisation interaction with its physical and social environment as stated in corporate annual reports or social reports. It has been argued that the increased corporate transparency through social accounting enhances corporate image and maintains organisation's legitimacy. Sweeny and Coughlan as cited in Mozes, Josman and Yaniv (2011) argue that many companies 
recognises the benefits of being seen as socially responsible and attach importance to reporting their corporate social responsibility activities. Despite its benefits to both society and reporting entity, SEA has not received full regulatory back up it deserves and has consequently been implemented on voluntary basis and concentrated in big companies of the developed world (Siddique, 2009).

Liu as cited in Abdel-Rahim and Abdel-Rahim (nd) advances three key factors for lack of adaption of environmental accounting and reporting at global level. They include the absence of clear-cut regulations and tools of implementation; the dispersed responsibilities of implementing and imposing the environmental disclosures among different agencies; and lack of experienced corporations' personnel to describe fully their corporations' environmental activities. At the accounting professional level, Diaconu (2009) gives four explanations for the absence of environmental reporting adaption. These are: failure on the part of the profession to capitalise on its potential for leadership; insufficient expertise to participate in environmental partnerships; attestation to environmental reports still not being considered as an accountant's function; and inadequacy of official standards to guide the treatment of most environmental issues.

On the back-drop of lack of regulation, shortage of accountants and perceived cost of social disclosures in the developing countries, implementation of social and environmental accounting and related academic investigations are still at infancy stage (Ismail \& Ibrahim, 2008). The few available studies that address social and environmental disclosures by companies in developing countries include those of Tsang (1998) in Singapore and Ismail and Ibrahim (2008) and Al-Khadash (2003) in Jordan. In Botswana just like other developing countries there is still lack of information on social and environmental disclosures by companies. This study attempts to add to the limited literature on social and environmental disclosure from developing countries. The study investigates the nature and extent of social and environmental disclosures amongst the parastatals and companies listed on the Botswana Stock Exchange. It also aims to find out whether there is a difference in the disclosure level between listed companies and parastatals. Lastly, the study seeks to determine whether size of an organisation, its ownership and type of industrial sector it operates in influences the extent of social and environmental disclosure.

\subsection{Botswana Perspective}

Under the strong government leadership and high level fiscal discipline, mining has been the backbone of Botswana's economy since the initial production of diamond in 1972 in Orapa. The subsequent period witnessed a huge increase in mining activities and currently mines in Botswana include copper, coal, diamond, gold, nickel and soda ash. Diamond mining alone accounts for more than one-third of GDP, 70-80\% of export earnings, and about half of the government's revenues (CIA World Fact Book and Other Sources, 2012).

Empirical evidence from other countries suggests that environmental disclosures are mostly made by the large companies that belong to environmentally sensitive industries such as mining and petroleum (Deegan \& Gordon, 1996). It is therefore expected that Botswana entities, operating in the mining industry would tend to disclose social and environmental information. Although not many mining companies are listed in the Botswana Stock Exchange and no single parastatal is engaged in mining, it is envisaged that because of institutional isomorphism non-mining listed companies may choose to imitate the mining companies operating in Botswana in practising social and environmental reporting.

Currently there is no statute which compels Botswana entities to report on their corporate social responsibilities. Therefore any information provided on organisations' social and environmental performance is mainly voluntary However, Botswana has two statutes which focus on measures to mitigate the businesses' negative effects on environment which we believe can have influence on corporates' decision on whether or not to report on environmental matters. These are: Environmental Impact Assessment Act of 2005 and Waste Management Act of 1998. The Environmental Impact Assessment Act requires a person intending to undertake a prescribed activity in Botswana to carry out environmental impact assessment which is defined as the process and procedure for evaluating and predicting the likely environmental impact of a proposed activity (Botswana Government, 2005). Failure to comply with this requirement attracts a monetary fine or a term of imprisonment. In section 7 the Act requires consultation with the surrounding community regarding the intended project.

The Waste Management Act aims at regulating the management of controlled waste in order to prevent harm to human, animal and plant life; to minimize pollution of the environment and to conserve natural resources, among other things (Botswana Government, 1998). The Act establishes the Department of Sanitation and Waste Management under the leadership of the Director. The department has responsibility of providing policy direction and leadership in all matters pertaining to sanitation and waste management. The Act further requires, 
among other things, the registration and licensing of the movement of controlled waste within or across Botswana boundaries; registration of waste disposal sites and licensing of waste management facilities.

Another influence on the choice to report on social and environmental accounting in Botswana entities may come from the Botswana's Vision 2016. One of the seven pillars of the vision which seeks to build a prosperous, productive and innovative nation calls for the establishment of sustainable level of withdrawal from country's water resources; and for preservation of environment and making prudent use of the natural resources (Botswana National Vision Council, 2016).

Global trends in sustainability reporting could also be one of the sources of influence that may prompt the Botswana entities to provide social and environmental information in their reports. For example, the Global Reporting Initiatives (GRI) provides a generally accepted framework for reporting on an organisation's economic, environmental and social performance. It encourages organisations to report on their environmental performance using specific criteria. Auditing firms in Botswana, in cognisance of global trends, persuade their clients to prepare the sustainability reports. For example, PriceWaterHouseCoopers organises annual competition for the best published Corporate Reports and Accounts and the best entity in a certain category gets a prize.

The rest of the paper provides a review of social and environmental reporting literature in the next section. The following sections lay out the hypotheses, the methodology, data analysis and discussion of findings followed by the conclusion.

\section{Literature Review}

\subsection{Motives for Social and Environmental Accounting}

Different explanations have been put forward as to what motivates an entity to report on effects of its economic actions to society. Results of several empirical studies lead to the conclusion that companies adopt the practice of social and environmental reporting because they are seeking legitimacy of their actions (legitimacy theory) (Guthrie \& Parker, 1989; O’ Donovan, 2002; Deegan \& Gordon, 1996). Legitimacy theory argues that corporate disclosures are made as reactions to environmental pressures (economic, social, and political) in order to legitimise the corporation's existence and actions. Other motives are discussed under stakeholder theory, decision usefulness theory and agency theory. Stakeholder theory suggests that a company is responsible to more stakeholders other than the providers of capital. Therefore managers voluntarily report on their social responsibility with intention of managing or manipulating most powerful stakeholders groups (shareholders, debt holders, employees, consumers, regulatory authorities and non-government organisations) (Gray, Owen, \& Adams,1996). Under decision usefulness theory social and environmental disclosures are considered to have a significant bearing on the decisions of the financial stakeholders. Companies disclose the impacts on their environment because financial stakeholders rely on those disclosures to make economic decisions regarding the reporting companies. Agency theory argues that social and environmental disclosures made voluntarily help the entity to reduce agency costs or prevents occurrence of future agency costs that could arise in the form of regulation (Belkaoul \& Karpik (1989).

\subsection{Social and Environmental Disclosure in Developed Countries}

Several researchers have written extensively on social and environmental disclosure in developed countries. These include Adams, Hill and Roberts (1998), Ernst and Ernst (1978), Gray (2001), Guthrie and Parker (1990), and Patten (1991). These studies suggest that reporting of social and environmental disclosure has improved over the years in developed countries. Araya quoted by Ismail and Ibrahim (2008) reported that multinational companies from developed countries are leading when it comes to producing information on environmental disclosure. The author reported that for the period 1990 to 2003, 58\% of all separate reports published around the world came from Europe, 20\% came from America (which included US, Canada and Brazil) and 20\% from Asia. Only $2 \%$ came from Africa and the Middle East.

\subsection{Social and Environmental Disclosure in Developing Countries}

Not much has been written about social and environmental disclosure in developing countries (Al-Khater \& Naser 2003). According to Abu Shiraz (1998), lack of regulation was one of the most common obstacle that authorities in developing countries were faced with in their efforts to encourage companies to disclose social and environmental issues. He also argued that the shortage of qualified accountants in developing countries was another reason why social and environmental disclosure took a long time to be developed. Abu Shiraz states that introducing corporate social and environmental accounting into the reporting system required a combination of expertise in various fields including law and engineering to name just a few. These skills were not available in developing countries at the time social and environmental disclosure started in developed countries. 
A study by Abu-Baker (2000) examined the extent of social and environmental reporting by Jordanian listed companies in 1997. Abu-Baker found that majority of the companies reported on social issues but paid less attention to issues that covered environmental, product and energy. Abu-Baker also discovered that Jordanian listed companies disclosed information that covered human resources and community involvement. Another study by Jahamani (2003) examined the extent, awareness and level of environmental responsibility of Jordanian companies and found that only $10 \%$ of the companies issued environmental reports as part of their annual reports. Studies on social and environmental disclosure in less developed countries have shown that the target has been mainly on human resources (Thompson \& Zakaria, 2004) and less on environmental issues (Rahman \& Muttakin, 2005).

\section{Hypotheses}

\subsection{Entity's Size}

Entity's size can be measured by looking at different factors such as turnover, numbers of employees and total assets. In the current study size is represented by total assets of an entity. Regardless of the factor used to represent the size of the entity, large firms are considered to have more sustainability impact and large footprints which make them more exposed to public scrutiny and find themselves under pressure to report (Rivet Software, 2010). Large firms are more likely to disclose more information to boost their cooperate image and to reduce political costs (Firth, 1979). Moreover, large entities have adequate resources at their disposal to enable them collect, analyse and present huge data at a lower cost. Studies like those of Alsaeed, (2006), Ismail and Ibrahim (2008) and Dhar and Mitra (2010) have found size of the firm to be a good explaining factor of social and environmental reporting.

It is therefore hypothesized that

$\mathrm{H}_{1}$ : There is a positive relationship between entity's size and the social and environmental disclosure.

\subsection{Industry Type}

Patten (1991) suggests that the industry to which a company belongs is crucial in determining the level of social and environmental reporting. The current study categorises the entities under study as manufacturing and service entities. For the purpose of this study manufacturing is extended to include mining companies and pharmaceuticals. The service organisations are the rest of the entities that do not fall under manufacturing and their examples include financial services, information technology and tourism. Manufacturing industries are considered to be the greater polluters and therefore they attract a lot of attention from the society. Hackston and Milne (1998) argue that manufacturing entities are expected to influence political visibility. The mining industry, in particular, is seen as having a negative impact on the environment (Guthrie \& Parker, 1989; Tilt \& Symes, 1999). It is therefore argued that manufacturing entities would provide more social and environmental information to mitigate political costs and the pressure from social activists.

There is good evidence that leads to conclusion that there is a positive association between level of social and environmental disclosure and manufacturing sector. Hackston and Milne (1998) reported that highly profitable manufacturing entities provide more social and environmental information than non-manufacturing entities. Abu-baker (2000) revealed that manufacturing industries are more likely to provide more information than service industries. Ismail and Ibrahim (2008) concluded that industry type is associated with disclosure of environmental issues. Furthermore, studies on the mining industry have shown higher levels of reporting on environmental issues, higher quality reports and use of guidelines to inform reporting (Deegan \& Gordon, 1996; Wilmshurst \& Frost, 2000; and Peck \& Sinding, 2003). Deegan and Gordon (1996) found a positive correlation between environmental sensitivity and the level of corporate environmental disclosure.

It is therefore hypothesized that

$\mathrm{H}_{2}$ : Manufacturing entities disclose more social and environmental information than service entities.

\subsection{Government Ownership}

Most parastatals in Botswana are hundred percent owned by the government. They are totally funded by the government or by the loans secured by the state. Only few of them sell their bonds through Botswana Stock Exchange. In 2011 only four of them did that. It is argued that parastatals will tend to disclose less information because it is not their primary intent to enhance shareholders' value. Unlike private sector entities, parastatals also need not to entice the creditors in order to access capital because government is more likely to gain easier access to various sources of financing. According to Huafang and Jianguo (2007) in China and Ismail and 
Ibrahim (2009) in Jordan there is evidence of significant negative association between government ownership and social and environmental disclosure. We therefore hypothesizes that

$\mathrm{H}_{3}$ : State owned entities disclose less social and environmental information than non-state owned entities.

\section{Methodology}

The population of the study was all 37 companies listed on the Botswana Stock Exchange and all 33 parastatals existing in Botswana (Local Enterprise Authority, 2009). Therefore a total of 70 entities were targeted for the study. Botswana Stock Exchange is a relatively new exchange. It was established in 1989 in the name of Botswana Share Market with only 5 listed companies and a single broking firm. The Act establishing the Botswana Stock Exchange was passed in 1994 enabling the exchange to operate as separate legal entity in November 1995. Its market capitalization grew from 254 million pula in 1989 to 411603.8 million pula at the end of 2011, domestic companies accounting for P30694.3 million pula and foreign companies making P 380 906.5 million pula. The total number of listed companies comprised of 24 domestic and 13 foreign companies. Under domestic companies there were 23 listed on the Main Board and one under Venture capital. Under the foreign companies, three were listed on the main board and ten under Venture capital. Companies listed in the main board are those that have been operating for more than five years and those that are classified under venture capital are those that have been in business for less than five years. The venture capital companies should have more than 200 shareholders and have not yet reported profit since they were listed. Both profit oriented and nonprofit oriented parastatals were included in the study.

Annual reports of these entities for the year 2010/2011 were used as source of data. Annual reports were used because they are considered to be the main document used by investors to make investment decisions (Deegan and Rankin (1997). Content analysis was used to measure the extent of disclosure. Guthrie and Abeysekera (2006) highlighted that for over two decades there have been ample studies on corporate social, ethical and environmental reporting that have used content analysis. Numbers of sentences instead of number of words or pages were used as a unit of analysis. Number of sentences was used because they require less judgement to count and its determination has been associated with fewer errors than number of words (Ismail and Ibrahim, 2009). Through the review of prior studies, (for example, Guthrie \& Parker, 1989; Ismail \& Ibrahim, 2009) we constructed the theme of social and environmental disclosures into human resources, community involvement, environment, and others. We further broke down these themes into thirteen items. Descriptive statistics were computed for each item.

The current study employs ordinary least square (OLS) regression model to investigate the effect of three characteristics of the firm on the level of social and environmental disclosures. The estimated model was as follows:

$$
S E D=\alpha+\beta_{1} S I Z E+\beta_{2} I N D U S R Y+\beta_{3} \text { OWNERSHIP }+\varepsilon
$$

Where:

$\alpha=$ a constant term representing number of sentences to be disclosed regardless of size, industry or ownership.

$\mathrm{SED}=$ the extent of social and environmental disclosure in number of sentences.

SIZE $=$ size of the entity measured by total assets in Botswana Pula

INDUSTRY = " 1 " if it is a manufacturing/mining entity, and " 0 " if it is a service entity.

OWNERSHIP $=$ " 1 " if it is a listed company, and " 0 " if it is a parastatal

$\varepsilon=$ error term

\section{Data Analysis and Discussion}

A total number of 47 annual reports consisting of 23 from parastatals and 24 from listed companies were obtained for this study. Out of 47 entities examined $6(13 \%)$ were not reporting on social and environmental issues ( 2 parastatals and 4 listed companies) which means $87 \%$ level of disclosure. This compares favourably with findings from other developing countries such as Jordan which showed $85 \%$ level of disclosure (Ismail \& Ibrahim, 2008) and India where 79\% level of disclosure was reported by Dhar and Mitra (2010). Therefore only 41 annual reports (21 parastatals and 20 listed companies) were analysed. The main reason why some parastatals were not analysed is because they did not have their annual reports of the relevant years ready at the end of data collection. We did not obtain all the annual reports of the targeted listed companies because of either some were new and had not started producing annual reports or others were foreign and their annual reports were prepared outside the country and could not be accessed through the internet. 
Table 1. SED in Botswana entities' annual reports by entities and sentences

\begin{tabular}{|c|c|c|c|c|c|c|}
\hline & & Entities Disclosing & & Sentences Disclo & & \\
\hline Theme & & No. of companies & $\% \mathrm{t}$ & No. of Sentences & $\%$ & Means \\
\hline \multicolumn{7}{|l|}{ Human Resources } \\
\hline Health and safety & & 21 & 51.2 & 234 & 8.4 & 11.14 \\
\hline Employees' & and & 23 & 56.1 & 201 & 7.2 & 8.74 \\
\hline \multicolumn{7}{|l|}{ Development } \\
\hline Incentives level & & 14 & 34.1 & 167 & 6.0 & 11.93 \\
\hline Other HR matters & & 26 & 63.4 & 394 & 14.2 & 15.15 \\
\hline Sub-total & & & & 996 & 35.8 & \\
\hline \multicolumn{7}{|l|}{ Community Involvement } \\
\hline Donations & & 24 & 58.5 & 293 & 10.6 & 12.21 \\
\hline Public Welfare & & 21 & 51.2 & 288 & 10.4 & 13.71 \\
\hline Other CI matters & & 17 & 41.5 & 235 & 8.5 & 13.82 \\
\hline Sub-total & & & & 816 & 29.5 & \\
\hline \multicolumn{7}{|l|}{ Environmental issues } \\
\hline Environmental expenditure & & 1 & 2.4 & 16 & 0.6 & 16.00 \\
\hline Pollution abetment & & 8 & 19.5 & 133 & 4.8 & 16.63 \\
\hline Environmental preservation & & 2 & 4.9 & 148 & 5.3 & 74.00 \\
\hline Recycling programmes & & 4 & 9.8 & 19 & 0.7 & 4.75 \\
\hline Other Environmental matters & & 10 & 24.4 & 252 & 9.1 & 25.20 \\
\hline Sub-total & & & & 568 & 20.5 & \\
\hline Other disclosures & & 15 & 36.6 & 394 & 14.2 & 26.3 \\
\hline Grand total & & & & 2774 & 100 & \\
\hline
\end{tabular}

Table 1 provides a summary of the social and environmental disclosures in annual reports of Botswana entities. It is apparent from Table1 that social and environmental reporting exists in the Botswana entities despite lack of regulation to direct the reporting. Among the three themes: human resources, community involvement and environmental matters, the most reported on theme is human resources which accounted for $35.8 \%$ of total disclosure. These findings agree with those of Abu-Baker (2000) and Thompson and Zakaria (2004) who reported that social and environmental disclosure in developing countries concentrate on human resources. This is a reflection of the importance attached to people for the survival of the organisations. The next highly reported area is community involvement responsible for $29.5 \%$ of total disclosures followed by environmental issues at $20.5 \%$. Other disclosures which, in this study, include information on matters such as customers, energy utilization and water usage, accounted for $14.2 \%$. Most entities (26 out of 41 ) give a more detailed account of the other matters under human resources than health and safety, employee's training and incentives. Other matters cover areas such as policies on employee behaviour, staff retrenchments, information sharing and staff unionisation. The next highest sub-theme reported on by the entities in Botswana was donation to communities which was mentioned by 24 out of 41 entities.

The means column in Table 1 shows the average sentences disclosed under each sub-theme. Environmental preservation reflects the highest mean number of sentences of 74 although only two companies provided information about that subtheme. These entities were foreign listed companies one from Tourism sector and another from mining sector. Recycling was the least attractive sub-theme with a mean number of sentences of 4.75 .

Table 2 presents the descriptive statistics of all variables. The maximum number of sentences disclosed by one of the 41 entities was 930 and the overall mean of sentences was 67.66. The entities examined had minimum total assets in Botswana currency of 4.5, maximum of 535.022.1 and mean of 16,059.3 million Botswana Pula. 
Table 2. Descriptive statistics

\begin{tabular}{|c|c|c|c|c|c|}
\hline & $\mathrm{N}$ & Minimum & Maximum & Mean & Std. Deviation \\
\hline SED (No, of sentences & 41 & 1 & 930 & 67.66 & 151.49 \\
\hline $\begin{array}{l}\text { SIZE (Total assets in } \\
\text { million Botswana } \\
\text { pula) }\end{array}$ & 41 & 4.5 & $535,022.1$ & $16,059.3$ & $83,285.5$ \\
\hline INDUSTRY & 41 & 0 & 1 & .22 & .419 \\
\hline OWNERSHIP & 41 & 0 & 1 & .49 & .506 \\
\hline
\end{tabular}

Table 3. SED mean sentences by company type, business sector and combination

\begin{tabular}{llll}
\hline & $\mathrm{N}$ & Mean & Std deviation \\
\hline $\begin{array}{l}\text { Company types } \\
\text { Parastatal }\end{array}$ & 21 & 28.86 & \\
$\begin{array}{l}\text { Listed company } \\
\text { Business Sector }\end{array}$ & 20 & 108.40 & 41.728 \\
$\begin{array}{l}\text { Service } \\
\text { Manufacturing /Mining }\end{array}$ & 32 & 60.94 & 207.534 \\
Combination & 9 & 91.56 & 162.657 \\
Service- parastatal & & & 106.777 \\
Manufacturing- parastatal & 20 & 30.05 & 42.443 \\
Service -listedcompany & 1 & 5.00 & \\
Manufacturing-listed company & 12 & 112.42 & 258.504 \\
\hline
\end{tabular}

Table 3 shows the overall mean number of sentences by company type, business sector and a combination of the two. The listed companies have the higher mean number of sentences of 108.4. Listed companies reported on social and environmental issues almost four times more than parastatals (mean sentences $=108.4$ ) which have a mean number of sentences of 28.86. These results are consistent with Farma and Jensen (1983) who suggest that a wider spread in share ownership has a positive impact on information disclosed in the annual reports of listed companies. At business sector level, manufacturing organisations provided more details of social and environmental matters (mean sentences $=92$ ) than service entities (mean sentences $=61$ ). These results agree with those of Abu-baker (2000) who reported that manufacturing sector is more likely to disclose information than other sectors. As mentioned above manufacturing sector is largely associated with pollution, contamination and other negative effects on environment and society, it is therefore expected of them to give more information on their efforts to mitigate the risks of their operations on environment. When company type is combined with industry, the service listed companies report the highest mean of sentences of 112 followed by manufacturing listed companies with mean sentences of 102 .

Table 4. Regression coefficients for independent variables combined

\begin{tabular}{llllll}
\hline Sources & Sum of Squares & df & Means square & F & Sig \\
\hline Regression & 95944.540 & 3 & 31981.513 & 1.440 & 0.247 \\
Residual & 822028.680 & 37 & 22216.991 & & \\
Total & 917973.220 & 40 & & & \\
\hline
\end{tabular}

Number of observation $=41, \mathrm{R}^{2}=0.105$, Adjusted $\mathrm{R}^{2}=0.032, \mathrm{~F}(3,37)=1.440$

\begin{tabular}{|c|c|c|c|c|c|}
\hline & \multicolumn{2}{|c|}{ Unstandardised Coefficients } & Standardised Coefficients & \multirow[t]{2}{*}{$\mathrm{t}$} & \multirow[t]{2}{*}{ Sig. } \\
\hline & $\mathrm{B}$ & Std error & Beta & & \\
\hline (CONSTANT) & 29.165 & 32.661 & & 0.893 & 0.378 \\
\hline SIZE & $3.444 \mathrm{E}-010$ & 0.000 & 0.189 & 1.166 & 0.251 \\
\hline INDUSTRY & -30.502 & 64.029 & -0.084 & -0.476 & 0.637 \\
\hline OWNERSHIP & 81.299 & 51.513 & 0.272 & 1.578 & 0.123 \\
\hline
\end{tabular}


Table 4 presents the results of the multiple regression analysis to find the predictive power of company's size, industry and ownership over the level of social and environmental disclosure. Table 4 shows that none of the independent variables can be used to predict the level of social and environmental voluntary reporting in Botswana entities as all of them have a P-value of greater than $10 \%$. The results are not stastistically significant at the conventional level of $5 \%$. The model depicts the adjusted R-square of 0.032 to signify that only $3.2 \%$ of variations in the level of SED can be explained by the independent variables. The F-ratio, a test statistic used to decide whether the model has statistically significant predictive capability, reveals that the model is statistically insignificant.

Size has an insignificant weak association with the SED. Only $18.9 \%$ of the variations in social and environmental disclosure can be predicted by size. These results do support the first hypothesis in the sense that the association between size and SED is positive as expected. However, the results do not fully agree with those of previous studies in the example of Ismail and Ibrahim (2009) and Dhar and Mitra (2010) who reported a positive and significant association between size and SED. In addition, size is correlated with the extent of SED $(\mathrm{r}=0.209)$ at 10 per significant level. This implies that as total assets increase there will be a corresponding increase in level of social and environmental disclosure but size cannot be used to estimate level of SED.

Type of industry has a very weak negative association $(\mathrm{r}=-0.084, \mathrm{P}=0.637)$ with level of social and environmental disclosure which is also statistically insignificant. This means that there is no association between industry type and level of social and environmental disclosure. These results are somehow consistent with findings of Ismail and Ibrahim (2009) who found no significant association between industry type and level of corporate social and environmental disclosure. It is worth noting that although manufacturing entities are providing more information on social and environmental issues than firms in the service sector (see Table 2), manufacturing cannot be used to estimate the level of SED in Botswana.

Interestingly, ownership appears to have the highest but weak positive association $(\mathrm{r}=0.272, \mathrm{P}=0.123)$ with extent of SED as compared to other independent variables. However, this association is close to be statistically significant at $10 \%$ level which leads to the mild acceptance of the hypothesis that state owned entities disclose less social and environmental information than non-state owned entities. These findings are close to the findings of Ismail and Ibrahim (2009) in Jordan and Huafang and Jiangu (2007) in China who found a negative association between state ownership and the level of voluntary disclosure.

\section{Conclusion}

This study shows the social and environmental disclosure amongst companies that are listed on the Botswana Stock Exchange and parastatals. Although corporate social and environmental disclosure is not a legal requirement to Botswana entities, the information is however important for some stakeholders such as government and environmental activists to determine which companies are social and environmentally responsible. The findings suggest that listed entities provide more social and environmental information than parastatals and manufacturing organisations report more on social responsibility matters than service organisations. This study also provides evidence that size, industry and ownership do not explain the level of social and environmental disclosure in Botswana entities. The implication of this study is that Botswana entities are not left behind in aligning themselves with international trends in carrying out their corporate social responsibilities and reporting about them which promote their legitimacy and their corporate image to their stakeholders. In addition, the results of this study may bring to the attention of the relevant authorities in Botswana the need to introduce social and environmental disclosure requirements to make Botswana entities better corporate citizens. Parastatals which have displayed a lower level of SED may be the primary target of such requirements. Future studies are advised to improve on this study by seeking the views of organisations in Botswana as to why they choose to disclose information about social and environmental issues in the absence of regulation requiring them to do so.

\section{References}

Abdel-Rahim, H. Y. M., \& Abdel-Rahim, Y. M. (nd). Green Accounting - a proposition for EA/ER conceptual implementation methodology. Journal of Sustainability and Green Business. Retrieved from http://www.aabri.com/manuscripts/10449.pdf on 24/07/2012

Abu-Baker, N. (2000). Corporate social reporting and disclosure practice in Jordan: An empirical investigation. Dirasat Journal, Administrative Sciences, 27(1), 249-263.

Abu Shiraz. (1998). Social Reporting: Nice Idea but... Australian CP, November, 58-59. 
Adams, C. A., Hill, W. Y., \& Roberts, C. B. (1998). Corporate social reporting practices in Western Europe: Legitimating Corporate Behaviours? British Accounting Review, 30(1), 1-21.

Al-Khadash, H. A. (2003). The accounting disclosure of social and environmental activities: A comparative study for the industrial Jordanian shareholding companies. Abhath Al-Yarmouk Journal: Humanities and Social Sciences, 19, 21-39.

Al-Khater, K., \& Naser, K. (2003). Users perception of corporate social responsibility and accountability: Evidence from an emerging economy. Managerial Auditing Journal, 18(6), 538-548. http://dx.doi.org/10.1108/02686900310482678

Alsaeed, K. (2006). The association between firm specific characteristics and disclosure. Managerial Auditing Journal, 12(6), 476-498. http://dx.doi.org/10.1108/02686900610667256

Belkaoui, A., \& Karpik, P. K. (1989). Determinants of the corporate decisions to disclose social information. Accounting, Auditing \& Accountability Journal, 2(1), 36-51. http://dx.doi.org/10.1108/09513578910132240

Botswana Government. (1998). Waste Management Act, 1998. Government Printer, Gaborone.

Botswana Government. (2005). Environmental Impact Assessment Act of 2005. Government Printer, Gaborone.

Botswana National Vision Council. (nd). Long Term Vision for Botswana: Vision 2016. Government Printer, Gaborone.

CIA World Fact book and other sources. (2012). Botswana economy 2012. Retrieved from http://www.theodora.com/wfbcurrent/botswana/botswana_economy.html

Dhar, S., \& Mitra, S. (2010). Extent and determinants of corporate social reporting in India. Indian Accounting Review, 14(2), 57-78.

Deegan, C., \& Gordon, B. (1996). A study of the environmental disclosure policies of Australian corporations. Accounting and Business Research, 26(3), 187-99. http://dx.doi.org/10.1080/00014788.1996.9729510

Deegan, C., \& Rankin, M. (1997). The materiality of environmental information to users of annual reports. Accounting, Auditing \& Accountability Journal, 10(4), 562-583. http://dx.doi.org/10.1108/09513579710367485

Diaconu, P. (2009). International accounting system and its major challenges in time. Journal of Modern accounting and auditing, 5(1), 14-19.

Ernst and Ernst. (1978). Social responsibility disclosure: survey of Fortune 500 annual reports. Cleveland, Ohio.

Farma, E. F., \& Jensen, M. J. (1983). Seperation of ownership and control. Journal of law and Economics, 26(2), 301-325. http://dx.doi.org/10.1086/467037

Firth, M. (1979). The impact to size, stock market listing, and auditors on voluntary disclosure in corporate annual reports. Accounting and Business Research, 9, 273-280. http://dx.doi.org/10.1080/00014788.1979.9729168

Gray, R. (2001). Thirty years of Social Accounting, Reporting and Auditing: What if anything we have learnt. Business Ethics A European Review, 10(1), 9-15. http://dx.doi.org/10.1111/1467-8608.00207

Gray, R., Owen, D., \& Maunders, K. (1987). Corporate Social Reporting: Accounting and Accountability. London: Prentice Hall.

Guthrie, J., \& Abeysekera, I. (2006). Content analysis of social, environmental reporting: What is new? Journal of Human Resources Costing and Accounting, 10(2), 114-126. http://dx.doi.org/10.1108/14013380610703120

Guthrie, J., \& Mathews, M. R. (1985). Corporate Social Reporting: A Comparative International Analysis. In Preston, L. E. (Ed.), Research in Corporate Social Performance and Policy (vol. 7, pp. 251-277).

Guthrie, J., \& Parker, L. D. (1989). Corporate Social Reporting: A Rebuttal of Legitimacy Theory. Accounting and Business Research, 19(76), 343-352. http://dx.doi.org/10.1080/00014788.1989.9728863

Guthrie, J., \& Parker, L. D. (1990). Corporate Social Reporting: A Comparative International Analysis. Advances in Public Interest Accounting, 3, 159-175.

Hackston, D., \& Milne, M. J. (1998). Some determinants of social and environmental disclosures in New Zealand companies. Accounting, Auditing and accountability Journal, 9(1), 77-108. http://dx.doi.org/10.1108/09513579610109987 
Huafang, X., \& Jianguo, Y. (2007). Ownership structure, board composition and corporate voluntary disclosure. Managerial Auditing Journal, 22(6), 604-619. http://dx.doi.org/10.1108/02686900710759406

Ismail, K. N. I. K., \& Ibrahim, A. H. (2008). Social and Environmental Disclosure in the Annual Reports of Jordanian Companies. Issues in Social and Environmental Accounting, 2(2), 198- 210.

Jahamani, Y. (2003). Green Accounting in Developing Countries: The Case of U.A.E and Jordan. Managerial Finance, 29(8), 37-45. http://dx.doi.org/10.1108/03074350310768418

Local Enterprise Authority. (2009). Government and Parastatals Procurement from SMEs Study Report. LEA Research and Development Division, Gaborone. Retrieved from http://www.lea.co.bw/uploads/files/Govt\%20Procurement\%20from\%20SME\%20complete\%20version.pdf? size $=1412297$

Mozes, M., Josman, Z., \& Yaviv, E. (2011). Corporate social responsibility organisational identification and motivation. Social responsibility Journal, 7(2), 310-325. http://dx.doi.org/10.1108/17471111111141558

O'Donovan, G. (2002). Environmental disclosures in the annual report: extending the alicability and predictive power of legitimacy theory. Accounting, Auditing \& Accountability Journal, 15(3), 344-371. http://dx.doi.org/10.1108/09513570210435870

Patten, D. M. (1991). Exposure, legitimacy, and social disclosure. Journal of Accounting and Public Policy, 10, 297-308. http://dx.doi.org/10.1016/0278-4254(91)90003-3

Peck, P., \& Sinding, K. (2003). Environmental and Social Disclosure and Data Richness in the Mining Industry. Business Strategy and the Environment, 12(3), 131-146. http://dx.doi.org/10.1002/bse.358

Rahman, M., \& Muttakin, M. (2005). Corporate Environmental Reporting Practices in Bangladesh: A Study of Some Selected Companies. The Cost and Management (Bangladesh), 33(4), 13-21.

Siddique, S. (2009). Revisiting the Literature on Enviromenal Reporting Practices in Annual Reports in Australia. International Review of Business Research papers, 5(2), 317-328.

Rivet Software. (2010). Sustainability Reporting:Definition, Directions \& Challenges. Retrieved from http://www.rivetsoftware.com/premium/Rivet-Software-White-Paper-Sustainability-Reporting.pdf

Thompson, P., \& Zakaria, Z. (2004). Corporate Social Responsibility Reporting in Malaysia: Progress and Prospects. Journal of Corporate Citizenship, 13, 125-136.

Tilt, C. A., \& Symes, C. F. (1999). Environmental Disclosure by Australian Mining Companies: Environmental Conscience or Commercial Reality? Accounting Forum, 23(2), 137-154. http://dx.doi.org/10.1111/1467-6303.00008

Tsang, E. W. K. (1998). A longitudinal study of corporate social reporting in Singapore: The case of the banking, food and beverages and hotel industries. Accounting, Auditing \& Accounting Journal, 11(5), 624-635. http://dx.doi.org/10.1108/09513579810239873

Wikipedia. (2012). Social accounting. Retrieved from http://en.wikipedia.org/wiki/Social_accounting

Wilmshurst, T. D., \& Frost, G. R. (2000). Corporate Environmental Reporting: A Test of Legitimacy Theory. $\begin{array}{lllll}\text { Accounting Auditing accountability Journal, } & \text { 13(1), }\end{array}$ http://dx.doi.org/10.1108/09513570010316126

\section{Copyrights}

Copyright for this article is retained by the author(s), with first publication rights granted to the journal.

This is an open-access article distributed under the terms and conditions of the Creative Commons Attribution license (http://creativecommons.org/licenses/by/3.0/). 